\title{
Primary resistance of HIV to antiretrovirals among individuals recently diagnosed at voluntary counselling and testing centres in the metropolitan region of Recife, Pernambuco
}

\author{
Ana Maria Salustiano Cavalcanti ${ }^{1,2}{ }^{+}$, Ana Maria de Brito ${ }^{3}$, Daniela Medeiros Salustiano ${ }^{2,4}$, \\ Kledoaldo Oliveira de Lima ${ }^{2}$, Sirleide Pereira da Silva', \\ Ricardo Sobhie Diaz ${ }^{5}$, Heloisa Ramos Lacerda ${ }^{2}$ \\ ${ }^{1}$ Setor de Virologia, Laboratório Central de Saúde Pública de Pernambuco, Recife, PE, Brasil \\ ${ }^{2}$ Programa de Pós-Graduação em Medicina Tropical, Universidade Federal de Pernambuco, Recife, PE, Brasil \\ ${ }^{3}$ Centro de Pesquisa Aggeu Magalhães-Fiocruz, Recife, PE, Brasil ${ }^{4}$ Centro de Testagem e Aconselhamento Herbert de Souza, \\ Cabo de Santo Agostinho, PE, Brasil ${ }^{5}$ Laboratório de Retrovirologia, Universidade Federal de São Paulo, São Paulo, SP, Brasil
}

\begin{abstract}
Determining the prevalence and type of antiretroviral (ARV) resistance among ARV-naïve individuals is important to assess the potential responses of these individuals to first-line regimens. The prevalence of primary resistance and the occurrence of recent infections among individuals with human immunodeficiency virus (HIV)/ acquired immune deficiency syndrome (AIDS) were identified among recently diagnosed patients at five sexually transmitted disease/AIDS testing and counselling centres in the metropolitan region of Recife (RMR), Pernambuco, Brazil, between 2007-2009. One-hundred and eight samples were analysed using the Calypte ${ }^{\circledR}$ BED assay. Males predominated (56\%), as did patients aged 31-50 years. Twenty-three percent presented evidence of a recent HIV infection. The median $\mathrm{CD}^{+}$T lymphocyte count was $408 \mathrm{cells} / \mathrm{mm}^{3}$ and the median viral load was 3.683 copies $/ \mathrm{mL}$. The prevalence of primary resistance was $4.6 \%$ (confidence interval $95 \%=1-8.2 \%$ ) based on criteria that excluded common polymorphisms in accordance with the surveillance drug resistance mutation criteria. The prevalence of resistance to non-nucleoside reverse transcriptase, nucleoside/nucleotide reverse transcriptase and protease inhibitors were $3.8 \%, 1.5 \%$ and $0.8 \%$, respectively. Fifty-seven percent of strains were from clade $B, 37.7 \%$ were clade $F$ and $3.1 \%$ were clade $C$; there were no statistically significant differences with respect to resistance between clades. Recent infection tended to be more common in men $(p=0.06)$ and in municipalities in the south of the RMR (Jaboatão dos Guararapes and Cabo de Santo Agostinho) $(p=0.046)$. The high prevalence of recent infection and the high prevalence of non-B strains in this poor Brazilian region merit further attention.
\end{abstract}

Key words: transmitted antiretroviral resistance - HIV subtype - Brazil - recent HIV infection

In Brazil, antiretroviral (ARV) therapy has been offered universally and free of charge to human immunodeficiency virus (HIV)-positive individuals since 1997. Currently, approximately 200,000 people are undergoing ARV treatment. The universal access to ARVs in Brazil has increased survival and improved the quality of life of patients with HIV/acquired immune deficiency syndrome (AIDS) (Teixeira et al. 2004). However, given the sequential use of ARVs in many Brazilian patients and the extensive use of non-boosted protease inhibitors (PIs) in the recent past, it is assumed that a high proportion of patients experience virologic failure and develop ARV resistance, which can lead to the transmission of resistant strains. Initial infection with resistant strains can be related to virologic failure when treatment is started (Gagliani et al. 2011). The likelihood that a transmitted virus may be resistant to at least one ARV varies considerably. This variation is related primarily

\footnotetext{
Financial support: LACEN-PE, CAPES/PROCAD-NF

+ Corresponding author: a_salustiano@yahoo.com.br

Received 7 June 2011

Accepted 27 February 2012
}

to the differences in access to therapy (universal versus limited), risk behaviour, compliance with treatment (Paredes et al. 2010) and inclusion of volunteers exposed to ARVs, but not aware of or not willing to disclose this exposure. In USA and Europe, the prevalence of transmitted ARV-resistant strains is between 5-18\%; in Asia, this prevalence is $13.8 \%$ and in Africa it ranges from 2.224\% (Ceccherini-Silberstein et al. 2010). There are also regional variations in the prevalence of transmitted ARV resistance over time, with different studies demonstrating stability (Chaix et al. 2009), increases (Wheeler et al. 2010) or decreases in this prevalence (Bracciale et al. 2009). Thus, local studies may play an important role in determining the prevalence of resistance among patients who have never previously taken ARVs, thereby avoiding the initial use of empirically ineffective ARVs and the use of more complex and more expensive ARV schemas than are needed to treat infected individuals in the region.

In Brazil, HIV/AIDS voluntary counselling and testing (VCT) centres have been set up in the municipalities in which $70 \%$ of Brazilian AIDS cases are found. With the implementation of VCT centres in Brazil, access to HIV testing has increased and many asymptomatic, infected individuals have sought these centres at earlier stages of the disease to verify their HIV status (Grangeiro 2007). 
Investigating the molecular epidemiology of samples from HIV-seropositive individuals who have been diagnosed at VCT centres is of fundamental importance in understanding the details of each localised epidemic in a given region of Brazil.

Recife is the capital of the state of Pernambuco (PE) in the Northeast Region of Brazil. This metropolitan region is an urban area with 3.6 million people (out of a total state population of 7.4 million). The Northeast Region of Brazil is considered less developed than the Southeast and South Regions of the country and the Northeast Region is experiencing an increasing prevalence of AIDS and higher AIDS-related mortality rates than are the southern Regions (MS 2010a). There are nine VCT centres located at strategic points throughout the metropolitan region of Recife (RMR); these VCT centres are located at selected clinics where there is a high demand for HIV testing. The five VCT centres located in the most populous municipalities of the metropolitan region, namely Cabo de Santo Agostinho, Jaboatão dos Guararapes, Olinda, Paulista and Recife, account for the largest number of patients tested for HIV-1 in the RMR. Most of these centres have specialised outpatient clinics funded primarily by resources from the Department of Sexually Transmitted Disease (STD)/AIDS and Viral Hepatitis of the Brazilian Ministry of Health (MS 2010b).

In this study we sought (i) to determine the prevalence of primary resistance and recent infection among HIV-1-seropositive individuals who had been recently diagnosed at the five most important VCT centres in the RMR, (ii) to compare the characteristics of individuals with recent and established infections and (iii) to analyse the socio-demographic characteristics of individuals with HIV-1 subtypes B and F.

\section{SUBJECTS, MATERIALS AND METHODS}

The users of the VCT centres selected for this study (Cabo de Santo Agostinho, Jaboatão dos Guararapes, Olinda, Paulista and Recife) were diagnosed as HIV positive by two different ELISA assays and one positive confirmatory test (immunofluorescence or western blot assay). When these individuals returned to the centres to receive their results, they were informed of this study during the post-test counselling. Those individuals who agreed to participate signed the informed consent document and then blood was collected for HIV characterization and for the Calypte BED assay. Along with the specific form for the project, the samples were sent to the Virology Sector of Central Public Health Laboratory (LACEN)-PE and stored at $-70^{\circ} \mathrm{C}$.

Between July 2007-March 2009, the partial HIV genomes from 130 samples from individuals who had recently been diagnosed with HIV-1 and had never received ARV treatment were sequenced.

Viral RNA was extracted using the QIAamp ${ }^{\circledR}$ RNA Mini Kit (Qiagen, Germany). For reverse transcription of the RNA to yield cDNA, polymerase chain reaction amplification followed by genetic sequencing of the product was performed using the TRUGENE ${ }^{\circledR}$ HIV-1 Genotyping Assay (Siemens Diagnostics, USA). This genotyping assay detects genomic HIV mutations in the protease (codons 1-99) and the reverse transcriptase (codons 10297) regions of the pol gene.

The genetic sequences generated were analysed using the OpenGene ${ }^{\circledR}$ DNA Sequencing System (Siemens Diagnostics, USA). ARV resistance mutations and subtypes were submitted to the Stanford HIV Drug Resistance Database (hivdb.stanford.edu) and the subtypes were further confirmed using SIMPLOT version 2 . The mutations were identified in accordance with the surveillance drug resistance mutation (SDRM) criteria, which exclude common polymorphisms in the evaluation of transmitted ARV-resistant HIV (Bennett et al. 2009). The Calypte ${ }^{\circledR}$ BED assay (Calypte Biomedical Corporation) was performed in accordance with the manufacturer's instructions for the serological differentiation of recent seroconverters and long-term seroconverters.

The patients' socio-demographic and laboratory data were retrieved from the sample referral records sent from the VCT centre to the Virology Sector of LACENPE based on the user history provided by the Laboratory Test Result System database. The viral load and CD4 ${ }^{+}$ T lymphocyte count were retrieved from Brazilian System of Laboratory Examinations Control. The Logistics Control System of Medicines (SICLOM), managed by the State Coordination of STD and AIDS of PE, was consulted to identify patients with prior exposure to ARVs among those patients whose viruses harboured resistance mutations.

Data were analysed using STATA version 9.0. Descriptive statistics are presented as percentages, medians and percentiles. The Kolmogorov-Smirnov test for normality was applied to the CD4 count and viral load data and the null hypothesis was rejected; thus, the nonparametric Mann-Whitney test was used. We used the chi-squared test to compare proportions and we used Fisher's exact test when necessary. Statistical significance was set at the $5 \%$ level.

The study was approved by the Ethical in Research Committee of the Federal University of Pernambuco (protocol CEP/CCS/UFPE 120/07).

\section{RESULTS}

The patients' characteristics are shown in Table I. Samples were available from 108 individuals for testing for recent HIV infection and this testing revealed a prevalence of recent infection of $23.1 \%$ [confidence interval (CI) 95\% 14.9-31.3\%]. The prevalence of primary resistance was $6.1 \%$ (CI 95\% 1.6-10.6\%) based on International AIDS Society (IAS) (2008) (Johnson et al. 2008) table of mutations and $4.6 \%$ (CI 95\% 1.0 $8.2 \%$ ) based on the SDRM criteria (2009) (Bennett et al. 2009). Subtype B was the most prevalent $(56.9 \%)$ in the study population, followed by F (37.7\%), C (3.1\%) and $\mathrm{B} / \mathrm{F}(2.3 \%)$.

The mutations associated with resistance to reverse transcriptase inhibitors and PIs that were found among eight patients in the study are detailed in Table II, which also presents the socio-demographic and laboratory data of these patients.

The percentage of patients with recent infection varied among the studied municipalities. The prevalence of recent infection was greater among patients from the city 
of Recife and the southern region of the RMR (Jaboatão dos Guararapes and Cabo de Santo Agostinho), whereas the prevalence of chronic infection was greater among those patients from the northern region of the RMR (Olinda and Paulista). There was a trend towards a higher prevalence of recent infections among men (Table III).

There were no statistically significant differences with respect to socio-demographic and laboratory characteristics between individuals with and without resistance or between individuals infected by the $\mathrm{B}$ and $\mathrm{F}$ subtypes of HIV-1 (Table IV).

\section{DISCUSSION}

The prevalence of primary resistance to ARVs (considering only reverse transcriptase inhibitors and PIs) observed in this study was 4.6\% (CI 95\% 1-8.2\%) when using the SDRM criteria, which exclude common polymorphisms (Bennett et al. 2009).

Due to the high cost of monitoring ARV resistance by means of genotyping, the World Health Organization recommends that the surveillance of resistance in small geographical areas should be stratified by applying a sequential sampling method known as threshold surveying

\section{TABLE I}

Socio-demographic and laboratory characteristics of the samples sequenced from voluntary counselling and testing (VCT) volunteers

\begin{tabular}{|c|c|c|c|}
\hline \multirow[b]{2}{*}{ Characteristics } & \multirow[b]{2}{*}{ Total } & \multicolumn{2}{|c|}{$\begin{array}{l}\text { Individuals with primary } \\
\text { resistance }\end{array}$} \\
\hline & & IAS & SDRM \\
\hline Total $[\mathrm{n}(\%)]$ & $130(100)$ & $8(6.1)$ & $6(4.6)$ \\
\hline \multicolumn{4}{|l|}{ Age group [n (\%)] } \\
\hline Under 30 years & $57(43.8)$ & $5(62.5)$ & $5(83.3)$ \\
\hline 31 years or over & $73(56.2)$ & $3(37.5)$ & $1(16.7)$ \\
\hline \multicolumn{4}{|l|}{$\operatorname{Sex}[\mathrm{n}(\%)]$} \\
\hline Male & $69(53.1)$ & $5(62.5)$ & $5(83.3)$ \\
\hline Female & $61(46.9)$ & $3(37.5)$ & $1(16.7)$ \\
\hline \multicolumn{4}{|l|}{ VCT of origin [n (\%)] } \\
\hline Recife & $12(9.2)$ & - & - \\
\hline Olinda & $9(6.9)$ & - & - \\
\hline Paulista & $27(20.8)$ & $2(25)$ & $2(33.3)$ \\
\hline Jaboatão dos Guararapes & $28(21.5)$ & $2(25)$ & $1(16.7)$ \\
\hline Cabo de Santo Agostinho & $54(41.5)$ & $4(50)$ & $3(50)$ \\
\hline \multicolumn{4}{|l|}{ Exposure category $^{a}[\mathrm{n}(\%)]$} \\
\hline MSM & $21(16.2)$ & $1(50)$ & $1(50)$ \\
\hline HTS/male & $45(34.6)$ & $4(50)$ & $4(50)$ \\
\hline HTS/female & $51(39.2)$ & $2(66.7)$ & $1(33.3)$ \\
\hline HIV+ partner & $11(8.5)$ & $1(100)$ & - \\
\hline Sex worker & $2(1.5)$ & - & - \\
\hline \multicolumn{4}{|l|}{ HIV subtype [n (\%)] } \\
\hline $\mathrm{B}$ & $74(56.9)$ & $6(75)$ & $5(83.3)$ \\
\hline $\mathrm{F}$ & $49(37.7)$ & $2(25)$ & $1(16.7)$ \\
\hline $\mathrm{C}$ & $4(3.1)$ & - & - \\
\hline $\mathrm{BF}$ & $3(2.3)$ & - & - \\
\hline \multicolumn{4}{|l|}{ Recent infection $^{b}[\mathrm{n}(\%)]$} \\
\hline Positive & $25(23.1)$ & $1(25)$ & $2(50)$ \\
\hline Negative & $83(76.9)$ & $3(75)$ & $2(50)$ \\
\hline \multicolumn{4}{|l|}{$\mathrm{CD} 4(\text { cells } / \mathrm{mL})^{c}$} \\
\hline Median & 408 & 470 & 428 \\
\hline Interquartile interval & $195-693$ & $332-544$ & $256-635$ \\
\hline \multicolumn{4}{|l|}{ Viral load $(\text { copies } / \mathrm{ml})^{c}$} \\
\hline Median & 3.683 & 17.671 & 53.259 \\
\hline Interquartile interval & $208-24.224$ & $4.095-67.776$ & $20.947-179.220$ \\
\hline
\end{tabular}

$a$ : the responses were not mutually exclusive; $b$ : 22 samples were not tested (16.9\%): of these, three patients had primary resistance according to International AIDS Society (IAS) and two patients according to surveillance drug resistance mutation (SDRM); for 34 patients, there was no information on the T CD4 lymphocyte count and viral load; HIV: human immunodeficiency virus; HTS: heterosexual; MSM: man who have sex with man. 
TABLE II

Individuals with drug resistance mutations

\begin{tabular}{|c|c|c|c|c|c|c|c|c|c|}
\hline \multirow[b]{2}{*}{ TCC-sample } & \multirow[b]{2}{*}{ Sex } & \multirow[b]{2}{*}{ Age } & \multirow{2}{*}{$\begin{array}{l}\text { Exposure } \\
\text { category }\end{array}$} & \multirow[b]{2}{*}{ Sub-type } & \multicolumn{3}{|c|}{ Mutations } & \multirow{2}{*}{$\begin{array}{l}\text { Recent } \\
\text { infection }\end{array}$} & \multirow{2}{*}{$\begin{array}{c}\text { CD4/viral } \\
\text { load }\end{array}$} \\
\hline & & & & & NRTI & NNRTI & PI & & \\
\hline Cabo-24913 & $\mathrm{F}$ & 25 & Partner HIV+ & B & - & $108 \mathrm{I}^{a}$ & - & - & $480 / 1.093$ \\
\hline Cabo-29524 & M & 27 & MSM & $\mathrm{F}$ & - & $103 \mathrm{~N}$ & - & Negative & - \\
\hline Cabo-14149 & M & 26 & HTS & $\mathrm{B}$ & $184 \mathrm{~V}$ & 101E, 190S & - & Positive & - \\
\hline Cabo-93 & M & 32 & HTS & $\mathrm{B}$ & $184 \mathrm{~V}, 215 \mathrm{~F}, 219 \mathrm{~N}$ & $103 \mathrm{~N}, 106 \mathrm{I}, 230 \mathrm{~L}$ & - & Positive & $566 / 470.000$ \\
\hline Jaboatão-36720 & $\mathrm{F}$ & 45 & HTS & $\mathrm{F}$ & - & $108 \mathrm{I}^{a}$ & - & Negative & $460 / 1.754$ \\
\hline Jaboatão-37415 & M & 30 & HTS & B & - & - & $\begin{array}{c}46 \mathrm{I}, 73 \mathrm{~S} \\
82 \mathrm{~A}, 90 \mathrm{M}\end{array}$ & Negative & $842 / 82.294$ \\
\hline Paulista-14785 & M & 47 & HTS & $\mathrm{B}$ & - & $190 \mathrm{~A}$ & - & - & 155/11.119 \\
\hline Paulista-16350 & $\mathrm{F}$ & 32 & HTS & $\mathrm{B}$ & - & $225 \mathrm{H}$ & - & - & $290 / 24.224$ \\
\hline
\end{tabular}

$a$ : mutation related to resistance only in the International AIDS Society classification; HIV: human immunodeficiency virus; HTS: heterosexual; MSM: man who have sex with man; NNRTI: non-nucleoside reverse-transcriptase inhibitor; NRTI: nucleoside reverse-transcriptase inhibitor; PI: protease inhibitor.

of HIV resistance, thus enabling the use of a small set of samples $(\mathrm{n} \leq 50)$. This method classifies HIV resistance into three categories of prevalence: low $(\leq 5 \%)$, moderate $(5-15 \%)$ and high ( $\geq 15 \%)$ (Myatt et al. 2008).

In Brazil, two major studies on the prevalence of primary HIV drug resistance were published in 2009. The first included 400 participants from 13 Brazilian cities. It is worth noting that only one centre, in Salvador (in the Northeast Region), was located outside of the South and Southeast Regions and that 220 samples originated from the state of São Paulo (SP). Using the IAS criteria, the percentage of HIV-positive individuals whose viruses harboured resistance mutations was 5.7\% (Sprinz et al. 2009). In the present study, using samples from the RMR, the observed prevalence of resistance mutations was determined to be $6.1 \%$ when using the IAS criteria; this prevalence is very similar to that reported by Sprinz et al. (2009).

One evaluation carried out at a national level was the study of the National Network for the Surveillance of Drug Resistance in Brazil (HIV-BResNet), which results were published in 2009. This study included 210 recently diagnosed individuals from six state capitals in Brazil, of which two capitals were in the Southeast Region (São Paulo and Rio de Janeiro), one in the South Region (Porto Alegre), one in the Central-West Region (Brasília), one in the North Region (Belém) and one in the Northeast Region (Salvador). The individuals were classified according to HIV mutations based on the SDRM criteria. In this study, $8.1 \%$ of the isolates harboured resistance mutations. The levels of resistance in São Paulo, Rio de Janeiro and Belém were intermediate (between 5-15\%), whereas the levels were low $(<5 \%)$ in Brasília, Porto Alegre and Salvador (Inocêncio et al. 2009).

Using the SDRM criteria, the present study showed that $4.6 \%$ of the strains had resistance mutations; this result coincides with the low resistance prevalence that has been detected outside of the Southeast Region, which is the epicenter of the HIV epidemic in Brazil
(Inocêncio et al. 2009). These results are also similar to the results of a study conducted in Recife in 2002 that showed that $3.6 \%$ of HIV-positive patients were infected with viruses that harboured resistance-related mutations (Medeiros et al. 2006).

Regarding the Northeast Region, data on the resistance of HIV to drugs in the states of Bahia and Ceará (CE) have recently been published. The HIV BResNet study showed that there was a low rate of resistance to drugs - less than 5\% - in Salvador (Inocêncio et al. 2009). A study conducted in CE found an intermediate rate of resistance, 9.5\% (Arruda et al. 2010), which was higher than the rates of resistance found in the two major Brazilian studies that included states outside of the Southeast Region. Given the differences in the data among these studies, in addition to the similarities among and the proximity of the three northeastern capitals, the precise composition of the populations in each study needs to be determined.

According to the analysis in the present study using the SDRM criteria, $3.84 \%$ of the mutations observed were associated with non-nucleoside reverse-transcriptase inhibitors (NNRTIs), 1.53\% with NRTIs and $0.77 \%$ with PIs; this profile is similar to the profiles observed recently in Brazil (Inocêncio et al. 2009, Sprinz et al. 2009) and elsewhere (Little et al. 2001).

From the analysis of the frequency of mutations associated with each class of ARVs, we found that there were more mutations associated with NNRTIs, a finding that was absent from an earlier study carried out in Recife in 2002 (Medeiros et al. 2006) and from a nationwide study (Brindeiro et al. 2003).

Regarding NRTIs, unlike in other studies, in this study two of our samples contained viruses with the $184 \mathrm{~V}$ mutation and only one sample contained a virus with the $215 \mathrm{~F}$ mutation. It is important to emphasize that the $184 \mathrm{~V}$ mutation was found in the viruses of two individuals with recent infections, which may explain the presence of this mutation because there is a trend for this mutation to be- 
TABLE III

Socio-demographic and laboratory data of HIV infected volunteers according to infection status

\begin{tabular}{|c|c|c|c|}
\hline Characteristics & Recent seroconverters & Long-term seroconverters & $\mathrm{p}$ \\
\hline Total $(\mathrm{n}=108)[\mathrm{n}(\%)]$ & $25(23.1)$ & $83(76.9)$ & 0.000 \\
\hline \multicolumn{4}{|l|}{ Age group [n (\%)] } \\
\hline Under 30 years & $14(56)$ & $37(44.6)$ & 0.316 \\
\hline 31 or over & $11(44)$ & $46(55.4)$ & - \\
\hline \multicolumn{4}{|l|}{$\operatorname{Sex}[\mathrm{n}(\%)]$} \\
\hline Male & $18(72)$ & $42(50.6)$ & 0.060 \\
\hline Female & $7(28)$ & $41(49.4)$ & - \\
\hline \multicolumn{4}{|l|}{$\mathrm{VCT}$ of origin $[\mathrm{n}(\%)]$} \\
\hline Recife & $5(20)$ & $7(8.4)$ & 0.046 \\
\hline North part of RMR, Olinda, Paulista & $3(12)$ & $29(34.9)$ & - \\
\hline $\begin{array}{l}\text { South part of RMR, Jaboatão dos Guararapes, } \\
\text { Cabo de Santo Agostinho }\end{array}$ & $17(68)$ & $47(56.6)$ & - \\
\hline \multicolumn{4}{|l|}{ HIV subtype [n (\%)] } \\
\hline $\mathrm{B}$ & $15(60)$ & $44(53)$ & $0.600^{b}$ \\
\hline $\mathrm{F}$ & $8(32)$ & $35(42.2)$ & - \\
\hline Other & $2(8)$ & $4(4.8)$ & - \\
\hline \multicolumn{4}{|l|}{ Exposure category $^{a}[\mathrm{n}(\%)]$} \\
\hline MSM & $7(28)$ & $11(13.3)$ & $0.161^{b}$ \\
\hline HTS & $16(64)$ & $68(81.9)$ & - \\
\hline HIV+ partner & $2(8)$ & $4(4.8)$ & - \\
\hline \multicolumn{4}{|l|}{ Primary resistance (IAS/SDRM) [n (\%)] } \\
\hline Yes & $2(8)$ & $3(3.6)$ & 0.327 \\
\hline No & $23(92)$ & $80(96.4)$ & - \\
\hline \multicolumn{4}{|l|}{ Main mutations [n (\%)] } \\
\hline \multicolumn{4}{|l|}{ NRTI } \\
\hline Yes & $2(100)$ & - & Not performed \\
\hline No & - & $3(100)$ & - \\
\hline \multicolumn{4}{|l|}{ NNRTI } \\
\hline Yes & $2(100)$ & $2(66.7)$ & Not performed \\
\hline No & - & $1(33.3)$ & - \\
\hline \multicolumn{4}{|l|}{ PI } \\
\hline Yes & - & $1(33.3)$ & Not performed \\
\hline No & $2(100)$ & $2(66.7)$ & - \\
\hline \multicolumn{4}{|l|}{ CD4 (cells/mL) } \\
\hline Median $\left(\mathrm{P}_{25}-\mathrm{P}_{75}\right)$ & - & - & $0.275^{c}$ \\
\hline \multicolumn{4}{|l|}{ Viral load (copies/mL) } \\
\hline $\operatorname{Median}\left(\mathrm{P}_{25}-\mathrm{P}_{75}\right)$ & - & - & $0.498^{c}$ \\
\hline
\end{tabular}

$a$ : the responses were not mutually exclusive; $b$ : Fisher's exact test; $c$ : Mann-Whitney test; HIV: human immunodeficiency virus; HTS: heterosexual; IAS: International AIDS Society; MSM: man who have sex with man; NNRTI: non-nucleoside reverse-transcriptase inhibitor; NRTI: nucleoside reverse-transcriptase inhibitor; PI: protease inhibitor; RMR: Recife metropolitan region; SDRM: surveillance drug resistance mutation; VCT: voluntary counselling and testing.

come undetectable over time among individuals infected with ARV-resistant strains (Jain et al. 2011).

The present study revealed a high prevalence of recent infections $(23 \%)$, but there were no significant differences in the prevalence of mutations between the recently and chronically infected populations (Fisher's exact test, $\mathrm{p}=0.327$ ). Two samples from patients with recent infections and two samples from patients with chronic infections contained viruses that harboured NNRTI-related mutations, whereas NRTI-related mutations were found only in the viruses from the recently infected group (in 2 samples). The only sample with a mutation related to a PI was found among the patients with chronic infections. These findings most likely reflect the greater circulation of NNRTI-resistant strains, owing to the fact that NNRTIs are generally used in first-line regimens in Brazil (MS 2008).

Recent infections tended to be more common in men, in the municipality of Recife and in the southern part of the RMR (Jaboatão dos Guararapes and Cabo de Santo 


\section{TABLE IV}

Characteristics of study population by human immunodeficiency virus (HIV)-1 subtype ${ }^{a}$ and comparison of socio-demographic characteristics among patients infected with subtypes $\mathrm{B}, \mathrm{F}$ and $\mathrm{C}$

\begin{tabular}{|c|c|c|c|c|c|}
\hline \multirow[b]{2}{*}{ Characteristics } & \multicolumn{4}{|c|}{$\begin{array}{c}\text { Subtypes } \\
\text { n (\%) }\end{array}$} & \multirow[b]{2}{*}{$\mathrm{p}^{b}$} \\
\hline & $\begin{array}{c}\text { B } \\
(n=74)\end{array}$ & $\begin{array}{c}F \\
(n=49)\end{array}$ & $\begin{array}{c}C \\
(n=4)\end{array}$ & $\begin{array}{c}\text { BF } \\
(n=3)\end{array}$ & \\
\hline \multicolumn{6}{|l|}{ Age group } \\
\hline Under 30 years & $32(43.2)$ & $22(44.9)$ & $1(25)$ & $2(66.7)$ & 0.856 \\
\hline $31-50$ years & $42(56.8)$ & $27(55.1)$ & $3(75)$ & $1(33.3)$ & - \\
\hline \multicolumn{6}{|l|}{ Sex } \\
\hline Male & $43(58.1)$ & $24(49)$ & $2(50)$ & $0(0)$ & 0.418 \\
\hline Female & $31(41.9)$ & $25(51)$ & $2(50)$ & $3(100)$ & - \\
\hline \multicolumn{6}{|l|}{ VCT of origin } \\
\hline Recife & $9(12.2)$ & $3(6.1)$ & - & - & 0.469 \\
\hline North part of RMR ${ }^{b}$, Olinda, Paulista & $20(27)$ & $12(24.5)$ & $2(50)$ & $2(66.7)$ & - \\
\hline $\begin{array}{l}\text { South part of RMR }{ }^{b} \text {, Jaboatão dos Guararapes, } \\
\text { Cabo de Santo Agostinho }\end{array}$ & $45(60.8)$ & $34(69.4)$ & $2(50)$ & $1(33.3)$ & - \\
\hline \multicolumn{6}{|l|}{ Exposure category } \\
\hline MSM & $12(16.2)$ & $9(18.4)$ & - & - & $0.948^{c}$ \\
\hline HTS & $57(77)$ & $37(75.5)$ & $3(75)$ & $3(100)$ & - \\
\hline HIV+ partner & $5(6.8)$ & - & $1(25)$ & - & - \\
\hline \multicolumn{6}{|l|}{ Primary resistance } \\
\hline IAS & $6(8.1)$ & $2(4.1)$ & - & - & $0.607^{c}$ \\
\hline SDRM & $5(6.8)$ & $1(2)$ & - & - & $0.446^{c}$ \\
\hline
\end{tabular}

$a$ : study by viral clades at pol region; $b$ : comparison between subtypes B-F; $c$ : Fisher's exact test; HTS: heterosexual; IAS: International AIDS Society; MSM: man who have sex with man; RMR: Recife metropolitan region; SDRM: surveillance drug resistance mutation; VCT: voluntary counselling and testing.

Agostinho). It should be noted that the severity of the AIDS epidemic continues to increase in the Northeast Region of Brazil. Recife currently ranks as the state capital with the fifth highest number of new cases of AIDS in Brazil, with a detection rate of 58.4 cases/100,000 persons in 2010 (MS 2010a). Regarding the southern part of the RMR, the larger number of recent infections is most likely due to the presence of the tourist resort of Porto de Galinhas and the industrial Port Complex of Suape, which is the new centre of economic development in the region. The availability of jobs at the resort and the port has resulted in the migration of young workers, some of them returning from the Southeast Region of Brazil (the epicenter of the AIDS epidemic in Brazil) back to their place of origin (IBGE, available from: ibge.gov.br/home/estatistica/populacao/ reflexoes_deslocamentos/deslocamentos.pdf).

It should be noted that the patient sample included in the present study, which was exclusively recruited at VCT centres from among individuals recently diagnosed HIV, exhibited a prevalence of recent infection of $23 \%$. The results for this sample may more accurately reflect the percentage of recent HIV infections in the general HIV-infected population in this region than the results for samples from studies conducted at hospitals that provide specialized care. We thus verified that over $75 \%$ of the infections had been present for more than six months, thereby increasing the likelihood of viral transmission. These results demonstrate the importance of more actions that are aimed at prevention and of easier access to HIV testing, particularly in the areas where the diagnosis was shown to have been made at a late stage, such as in the northern part of the RMR. However, a similar proportion of recent HIV infections was found by Puchhammer-Stöckl et al. (2005) among newly diagnosed cases of HIV infection in Austria; this population is considered to be knowledgeable about HIV transmission and had easy access to diagnosis and widely available ARV treatment. Another study that compared the immune status at presentation for HIV clinical care among two different cohorts from Rio de Janeiro and Baltimore demonstrated that more than $50 \%$ of the patients presented with CD4 counts $<350$ cells $/ \mathrm{mm}^{3}$ and $75 \%$ presented with viral loads $>10,000$ copies $/ \mathrm{mm}^{3}$ (Moreira et al. 2011). These findings reinforce the hypothesis that even in a population that is well informed about HIV, individual awareness of the risk of infection is still low.

As has been observed in all Regions of Brazil, except the South, there is a predominance of HIV subtype B. However, in the present study, a high percentage of subtype F $(37.7 \%)$ was detected in the RMR. This rate was much higher than that generally observed in other 
regions of the country (Inocêncio et al. 2009). In addition, it appears that there may be a trend towards an increase in the circulation of subtype $F$ in this particular Region; the prevalence of this subtype was already high (26\%) in Recife in 2002 according to a previous study (Medeiros et al. 2006). The prevalence of subtype F was $22 \%$ in another study carried out between 2002-2004 using samples of patients with secondary resistance in PE (Cavalcanti et al. 2007). An epidemic of B/F recombinant strains that include circulating recombinants forms 28 and 29 in approximately $50 \%$ of infected individuals was detected in the port city of Santos in the Southeast Region, where there are also high levels of transmitted resistance (Sucupira et al. 2007, Teixeira et al. 2010).

It is interesting to note that although subtype B is predominant in Brazil, there is a trend towards an increasing prevalence of subtype $C$ in the South and Southeast Regions of the country. In a recent study carried out in six Brazilian state capitals with ARV-naïve patients, Inocêncio et al. (2009) observed a rate of $69 \%$ of subtype $\mathrm{C}$ in Rio Grande do Sul; this rate is much higher than that found by Brígido et al. (2007). In addition, Brígido et al. (2011) discovered an increased presence of subtype $\mathrm{C}$ in SP. It is of note that resistance-related mutations may vary among different subtypes in Brazil (Munerato et al. 2010) and studies targeting non-B strains certainly merit further attention.

We recognize that the small number of samples and the small size of the genomic region of HIV characterized in this study may preclude more definitive conclusions. In addition, a further limitation was the sampling bias; a smaller number of samples from Recife was analyzed despite its being the largest city in the region. This sampling bias precluded making more comparisons between the isolates. However, we found that there is an increased prevalence of subtype $\mathrm{F}$ in this region.

Transmitted resistance is still low, but the profile of transmitted mutations may be changing in this region. Future trends need to be carefully observed and evaluated.

\section{REFERENCES}

Arruda E, Simões L, Sucupira C, Medeiros M, Arruda E, Diaz R, Lima A 2010. Intermediate prevalence of HIV type 1 primary antiretroviral resistance in Ceará state, Northeast Brazil. AIDS Res Hum Retroviruses 26: 1-3.

Bennett DE, Camacho RJ, Otelea D, Kuritzkes DR, Fleury H, Kiuchi M, Heneine W, Kantor R, Jordan MR, Schapiro JM, Vandamme AM, Sandstrom P, Boucher CAB, Vijver D, Rhee SY, Liu TF, Pillay D, Shafer RW 2009. Drug resistance mutations for surveillance of transmitted HIV-1 drug-resistance: 2009 update. PlosONE 4: 4724.

Bracciale L, Colafigli M, Zazzi M, Corsi P, Meraviglia P, Micheli V, Maserati R, Gianotti N, Penco G, Setti M, Di Giambenedetto S, Butini L, Vivarelli A, Trezzi M, De Luca A 2009. Prevalence of transmitted HIV-1 drug resistance in HIV-1-infected patients in Italy: evolution over 12 years and predictors. J Antimicrob Chemother 64: 607-615.

Brígido LFM, Ferreira JLP, Almeida VC, Rocha SQ, Ragazzo TG, Estevam DL, Rodrigues R, the São Paulo HIV Salvage Workgroup 2011. Southern Brazil HIV type 1 C expansion into the state of São Paulo, Brazil. AIDS Res Hum Retroviruses 27: 339-344.

Brígido LFM, Nunes CC, Oliveira Cm, Knoll RK, Ferreira JLP, Freitas CA, Alves MA, Dias C, Rodrigues R, the Research Capacity
Program 2007. HIV type 1 subtype C and CB Pol recombinants prevail at the cities with highest AIDS prevalence rate in Brazil. AIDS Res Hum Retroviruses 23: 1579-1585.

Brindeiro RM, Diaz RS, Sabino EC, Morgado MG, Pires IL, Brigido L, Soares MA, Cavalieri E, Fernandez J, Rodrigues R, Lauria C, Dantas MC, Barreira D, Teixeira PR, Tanuri A, the Brazilian Network for Drug Resistance Surveillance 2003. Brazilian Network for HIV Drug Resistance Surveillance (HIV-BResNet): results from the first national survey. AIDS 17: 1063-1069.

Cavalcanti AMS, Lacerda HR, Brito AM, Pereira S, Medeiros D, Oliveira S 2007. Antiretroviral resistance in individuals presenting therapeutic failure and subtypes of the human immunodeficiency virus type 1 in the Northeast Region of Brazil. Mem Inst Oswaldo Cruz 102: 785-792.

Ceccherini-Silberstein F, Cento V, Calvez V, Perno C-F 2010. The use of human immunodeficiency virus resistance tests in clinical practice. Clin Microbiol Infect 16: 1511-1517.

Chaix ML, Descamps D, Wirden M, Bocket L, Delaugerre C, Tamalet C, Schneider V, Izopet J, Masquelier B, Rouzioux C, Meyer L, Costagliola D, ANRS AC11 Resistance Group, Cohort PRIMO ANRS CO 6, FHDH ANRS CO4 Study Groups 2009. Stable frequency of HIV-1 transmitted drug resistance in patients at the time of primary infection over 1996-2006 in France. AIDS 23: 717-724.

Gagliani LH, Maia WTA, Sá-Filho D, Sucupira MC, Caseiro MM, Diaz RS 2011. The association between primary antiretroviral resistance and HAART virologic failure in a developing set. AIDS Res Hum Retroviruses 27: 251-256.

Grangeiro A 2007. Diagnóstico situacional dos Centros de Testagem e Aconselhamento. São Paulo, Instituto de Saúde, 2007. [accessed 01 outubro. 2011]. Available from: aids.gov.br/sites/default/files/ relatorio_situacional_cta.pdf.

Inocêncio LA, Pereira AA, Sucupira MCA, Fernandez JCC, Jorge CP, Souza DFC, Fink HT, Diaz RS, Becker IM, Suffert TA, Arruda MB, Macedo O, Simão M, Tanuri A 2009. Brazilian Network for HIV Drug Resistance Surveillance: a survey of individuals recently diagnosed with HIV. J Int AIDS Soc 12: 20.

Jain V, Sucupira MC, Bacchetti P, Hartogensis W, Diaz RS, Kallas EG, Janini LM, Liegler T, Pilcher CD, Grant RM, Cortes R, Deeks SG, Hecht FM 2011. Differential persistence of transmitted HIV-1 drug resistance mutation classes. J Infect Dis 15: 203: 1174-1181.

Johnson VA, Brun-Vézinet F, Clotet B, Günthard HF, Kuritzkes DR, Pillay D, Schapiro JM, Richman DD 2008. Update of the drug resistance mutations in HIV: December 2008 - International AIDS Society. Topics in HIV Medicine 16: 138-145.

Little SJ, Holte S, Routy JP, Daar ES, Markowitz M, Collier AC 2001. Antiretroviral drug susceptibility and response to initial therapy among recently HIV-infected subjects in North. Am Antiviral Ther 6 (Suppl. 1): 21.

Medeiros LB, Lacerda HR, Cavalcanti AMS, Albuquerque MFPM 2006. Primary resistance of human immunodeficiency virus type 1 in a reference center in Recife, Pernambuco, Brazil. Mem Inst Oswaldo Cruz 101: 845-849.

Moreira RI, Luz PM, Struchiner CJ, Morgado M, Veloso VG, Grinsztein B, Moore RD 2011. Immune status at presentation for HIV clinical care in Rio de Janeiro and Baltimore. J Acquir Immune Defic Syndr 57: 171-178.

MS - Brazilian Ministry of Health 2008. Recomendações para uso da terapia anti-retroviral em adultos e adolescentes com HIV/AIDS, 7th ed., MS, Brasília, 244 pp.

MS - Brazilian Ministry of Health 2010a. National Program of STD and AIDS 2010. [cited 2011 Jun 17]. Available from: aids.gov.br/ publicacao 2010/45974/boletim_2010_pdf_14544.pdf. 
MS - Brazilian Ministry of Health 2010b. National Program of STD and AIDS 2010. [cited 2010 Oct 15]. Available from: aids.gov.br/publicacao/diretrizes-para-organizacao-e-funcionamento-dos-cta.

Munerato P, Sucupira MC, Oliveros MP, Souza DF, Pereira AA, Janini LM, Inocêncio LA, Diaz RS 2010. HIV-1 antiretroviral resistance mutations in subtypes B, C and F in the city of São Paulo, Brazil. AIDS Res Hum Retroviruses 26: 265-273.

Myatt M, Bennet DE 2008. A novel sequential sampling technique for the surveillance of transmitted HIV drug resistance by cross-sectional survey for use in low resource settings. Antivir Ther 13 (Suppl. 2): 37-48.

Paredes R, Lalama CM, Ribaudo HJ, Schackman BR, Shikuma C, Giguel F, Meyer WA 3rd, Johnson VA, Fiscus SA, D’Aquila RT, Gulick RM, Kuritzkes DR, AIDS Clinical Trials Group (ACTG) A5095 Study Team 2010. Pre-existing minority drugresistant HIV-1 variants, adherence and risk of antiretroviral treatment failure. J Infect Dis 201: 662-671.

Puchhammer-Stöckl E, Schmied B, Rieger A, Sarcletti M, Geit M, Zangerle R, Hofmann H 2005. Low proportion of recent human immunodeficiency virus (HIV) infections among newly diagnose cases of HIV infection as shown by the presence of HIV-specific antibodies of low avidity. J ClinMicrobiology 43: 497-498.
Sprinz E, Netto EM, Lima MP, Furtado JJ, Eira M, Zajdenverg R, Madruga JV, Lewi DS, Machado AA, Pedro RJ, Soares MA 2009. Primary antirretroviral drug resistance among HIV type 1-infected individuals in Brazil. AIDS Res Hum Retroviruses 25: 861-867.

Sucupira NCA, Caseiro MM, Alves K, Tescarollo G, Janini LM, Sabino EC, Castelo A, Page-Shafer K, Diaz RS 2007. High levels of primary antiretroviral resistance genotypic mutations and B/F Recombinants in Santos, Brazil. AIDS Patient Care and STDS 21: $42-54$.

Teixeira D, Munerato P, Komninakis SC, Fusuma EE, Janini LM, Sucupira MC, Diaz RS 2010. The detection of in vivo and in vitro HIV-1 B/F profiles in Brazil using a real-time PCR assay for five HIV-1 genomic regions. AIDS Res Hum Retroviruses 26: 1-10.

Teixeira PR, Vitória MA, Barcarolo J 2004. Antiretroviral treatment in resource-poor settings: the Brazilian experience. AIDS 18 (Suppl. 3): 5-7.

Wheeler WH, Ziebell RA, Zabina H, Pieniazek D, Prejean J, Bodnar UR, Mahle KC, Heneine W, Johnson JA, Hall HI, Variant, Atypical and Resistant HIV Surveillance Group 2010. Prevalence of transmitted drug resistance associated mutations and HIV-1 subtypes in new HIV-1 diagnoses, US-2006. AIDS 24: 1203-1212. 